\title{
THE COMPETENCE OF MILLENNIAL ISLAMIC EDUCATION TEACHERS IN FACING THE CHALLENGES OF INDUSTRIAL REVOLUTION
}

\author{
Shalahudin Ismail ${ }^{1}$, Ma'mun Zahrudin $^{2}$, Uus Ruswandi ${ }^{3}$, Erihadiana ${ }^{4}$ \\ Pascasarjana Universitas Islam Negeri Sunan Gunung Djati Bandung, Indonesia \\ Shalahudinismail75@gmail.com,mamunzahrudin@gmail.com, uusruswandi@uinsgd.ac.id, \\ erihadiana@uinsgd.ac.id
}

\begin{abstract}
The purpose of this research is to examine how the competence of millennial Islamic education teachers in facing challenges in the era of the industrial revolution 4.0. The method used in this research is library research, in which the writer bases on data sources or references in the form of text from the opinions of experts that have been formulated in the form of books, journals, and others. The results of research conducted by researchers through several references state that the competence of millennial Islamic education teachers in facing challenges in the era of the industrial revolution 4.0 is character, performance, and literacy. The recommendations for further researchers are expected to study more broadly about the competence of millennial Islamic education teachers in facing the challenges of the industrial revolution 4.0
\end{abstract}

Keywords: Teacher Competence, Islamic Education Teacher, Industrial Revolution

\section{Abstrak}

Tujuan penelitian ini adalah untuk mengkeaji bagaimana kompetensi guru PAI milenial dalam menghadapi tantangan di era revolusi industri 4.0. Adapun metode yang digunakan dalam penelitian ini adalab penelitian kepustakaan (library research), dimana penulis mendasarkan pada sumber-sumber data atau referensi yang berbentuk teks dari pendapat para abli yang telah diformulasikan dalam bentuk buku, jurnal, maupun yang lainnya. Hasil penelitian yang dilakukan oleh peneliti melalui beberapa referensi menyebutkan bahwa kompetensi guru PAI masa kini dalam menghadapi tantangan di era revolusi industri 4.0 adalah karakter, kinerja, dan literasi. Adapun rekomendasi bagi peneliti selanjutnya diharapkan mengkaji lebih luas lagi mengenai kompetensi guru PAI masa kini dalam menghadapi tantangan revolusi industri 4.0

Kata Kunci : Kompetensi, Guru PAI, Revolusi Industri

\section{INTRODUCTION}

The term today or known as the present has penetrated various lines of community life in this virtual universe. Even though the education area is no exception. Teachers, students, and parents are part of the human education that does not escape the term. among students, netizens know him as today's students. Meanwhile, today's teachers are aimed at 
educators. No exception for parents who are referred to as parents today or often referred to as slang parents. ${ }^{1}$

Advances in information and communication technology (ICT) have had an impact on the learning process. With the development of ICT use, there are five shifts in the learning process, namely: (1) from training to performance, (2) from classrooms to anywhere and anytime, (3) from paper to online or channels, (4) physical facilities to facilities network, (5) from cycle time to real time. ${ }^{2}$

Realizing the importance of the teacher's role in learning. Muhibbin Syah in his book "Educational Psychology with a New Approach" argues that teachers in modern education as they are today are not just teachers, but must be learning directors. That is, every teacher is expected to be good at directing the learning activities of students in order to achieve learning success (academic performance) as set out in the objectives of teaching and learning activities. As a consequence, his duties and responsibilities have become more complex. The expansion of duties and responsibilities has a consequence of the emergence of special functions that are an integral part of the professional competence of teachers carried out by teachers. ${ }^{3}$

Teachers must have critical thinking skills to carry out various analyzes, assessments, evaluations, reconstruction, decision making that lead to rational and logical action ${ }^{4} \mathrm{~s}$. Creativity, that is, a teacher must be able to find new things that haven't been there before that are original. Communicative, that is, the teacher must be able to express new thoughts, ideas, knowledge, or information, both in writing and orally ${ }^{5}$. Collaborative, namely a teacher must be able to work together effectively and show respect for team members to achieve common goals ${ }^{6}$. In addition, in the learning process, the teacher must build interactions that can meet the psychological needs of students. A teacher must be able to make students feel able and give appreciation for their learning outcomes.

\footnotetext{
${ }^{1} \mathrm{Uda} \quad$ Uak, "Karakteristik Guru Zaman Now," https://www.matrapendidikan.com/2018/01/karakteristik-guru-zaman-now.html, 2018.

2 Dahliana dan Firman, "Kemampuan Guru Zaman Now,” Article, no. January (2019): 1-6.

${ }^{3}$ Muhibbin Syah, Psikologi Pendidikan dengan Pendekatan Baru (Bandung: PT. Remaja Rosdakarya, 2008). 94

4 Rivika Alda, Helen Boholano, dan Filomena Dayagbil, "Teacher Education Institutions in the Philippines towards Education 4.0," International Journal of Learning, Teaching and Educational Research 19, no. 8 (26 September 2020), http://www.ijlter.org/index.php/ijlter/article/view/2449; Hayward P. Andres, "Active teaching to manage course difficulty and learning motivation," Journal of Further and Higher Education 43, no. 2 (7 Februari 2019): 220-35, https://doi.org/10.1080/0309877X.2017.1357073; Ann Ryan Collins, Teacher in faith and virtue: Lanfranc of Bec's commentary on Saint Paul, Commentaria, v. 1 (Leiden ; Boston: Brill, 2007).

${ }_{5}$ Beatrice Avalos, "Chapter 9 Teacher Professional Development in Teaching and Teacher Education," dalam From Teacher Thinking to Teachers and Teaching: The Evolution of a Research Community, vol. 19, 0 vol., Advances in Research on Teaching 19 (Emerald Group Publishing Limited, 2013), 175-204, https://doi.org/10.1108/S1479-3687(2013)0000019012; Alfurqan Alfurqan dkk., "The Problematics of Islamic Religious Education Teacher In Using of Instructional Media at SD Negeri 06 Pancung Soal Pesisir Selatan," AlTa Lim Journal 26, no. 1 (28 Februari 2019): 56-64, https://doi.org/10.15548/jt.v26i1.526; Cornelius Brandmiller, Hanna Dumont, dan Michael Becker, "Teacher Perceptions of Learning Motivation and Classroom Behavior: The Role of Student Characteristics," Contemporary Educational Psychology, 11 Juni 2020, 101893, https://doi.org/10.1016/j.cedpsych.2020.101893.

6 Sadaf Umer Chhapra dkk., "Analysis of Students Perception about Teachers' Personality in the Academic Achievement," TARBIYA: Journal of Education in Muslim Society 5, no. 1 (28 Juni 2018): 101-15, https://doi.org/10.15408/tjems.v5i1.7098.

${ }^{7}$ Ernita; Rifa'tu; Maulidah; yanti Sofi Makiyah Susanti, "Peran Guru Fisika Di Era Revolusi Industri 4.0," Jurnal Diffraction 1, no. 1 (2019): 48-52.
} 
The question that often arises in the era of the Industrial Revolution 4.0 is will the existence of teachers be replaced by machines? This concern deserves to arise when many learning applications are mushrooming and easily accessible to students anytime and anywhere. In addition to applications in the form of learning media, online tutoring services are also available ${ }^{8}$. Students only need to register as members so they can access various facilities ranging from e-books, learning videos, practice questions to consultation with online teachers. However, the existence of this service cannot completely replace the teacher's position. This implanting character cannot be replaced by machines. This means that whenever a teacher is needed. ${ }^{9}$

The opinion above was strengthened by Supriono, who stated that in the era of the industrial revolution 4.0 the role of teachers was irreplaceable. However, professional teachers who are able to take advantage of rapid advances in information technology are needed. Teachers must be able to use it to improve the quality of the teaching and learning process in each education unit in order to prepare superior human resources with global competences. ${ }^{10}$

Ironically, the acceleration of digitalization in the era of the Industrial Revolution 4.0 has not yet been matched by the equal quality of teacher resources and this is the big problem faced in the development of educational progress in Indonesia ${ }^{11}$. The position of the teacher as the nation's educator, especially the teacher of Islamic Religious Education, occupies a strategic position in determining the millennial progress of the times in accordance with the values of Islamic teachings ${ }^{12}$. Data from Unesco in the 2016 Global Education Monitoring (GEM) Report, education in Indonesia only ranks 10th out of 14 developing countries. Meanwhile, an important component in education, namely teachers ranks 14 out of 14 developing countries in the world. The quality of education in Indonesia is still far from adequate. The size of the education budget does not necessarily increase the quality of education. The reason is that the quality of teachers is still problematic, with evidence of the results of the 2015 teacher competency test for example an average of only 44.5, which is far

${ }^{8}$ Dian Arumsari, "Pengaruh Media Pembelajaran Dan Keterampilan Pengelolaan Kelas Terhadap Prestasi Belajar Siswa SMK Negeri 5 Madiun," Assets: Jurnal Akuntansi Dan Pendidikan 6, no. 1 (30 April 2017): 13-25, https://doi.org/10.25273/jap.v6i1.1290; Daryanto, Media Pembelajaran (Bandung: Satu Nusa, 2011).

9 Duwi Retnaningsih, "Tantangan dan Strategi Guru di Era Revolusi Industri 4.0 dalam Meningkatkan Kualitas Pendidikan,” Prosiding Seminar Nasional, no. September (2019): 23-30, https://doi.org/ISBN: 9788-60253231-4-0.

${ }^{10}$ Michael Gewati, "Era Revolusi Industri Peran Guru Tak Tergantikan," https://edukasi.kompas.com/read/2018/11/28/17550091/di-era-revolusi-industri-40-peran-guru-taktergantikan-tapi?page=all, diakses 02 Juni 2020, 2018.

${ }^{11}$ Hasan Baharun dan Rohmatul Ummah, "Strengthening Students' Character in Akhlaq Subject Through Problem Based Learning Model," Tadris: Jurnal Keguruan Dan Ilmu Tarbiyah 3, no. 1 (29 Juni 2018): 21-30, https://doi.org/10.24042/tadris.v3i1.2205; Edward Howe dan Masahiro Arimoto, "Narrative Teacher Education Pedagogies from across the Pacific," dalam International Teacher Education: Promising Pedagogies (Part A), vol. 22, 0 vol., Advances in Research on Teaching 22 (Emerald Group Publishing Limited, 2014), 213-32, http://www.emeraldinsight.com/doi/full/10.1108/S1479-368720140000022014.

12 Wignyo Adiyoso dan Hidehiko Kanegae, “The Preliminary Study of the Role of Islamic Teaching in the Disaster Risk Reduction (A Qualitative Case Study of Banda Aceh, Indonesia)," Procedia Environmental Sciences, The 3rd International Conference on Sustainable Future for Human Security, SUSTAIN 2012, 3-5 November 2012, Clock Tower Centennial Hall, Kyoto University, JAPAN, 17 (1 Januari 2013): 918-27, https://doi.org/10.1016/j.proenv.2013.02.110; Muhammad Anas Ma'arif, “Analisis Konsep Kompetensi Kepribadian Guru PAI Menurut Az-Zarnuji,” ISTAWA 2, no. 2 (2017): 35-60, http://journal.umpo.ac.id/index.php/istawa/article/view/624. 
below the standard of 75. Even pedagogical competence, which is the main competence of teachers, has not been encouraging. There are still many teachers whose teaching methods are not good, the way of teaching in class is boring. This is the right moment to criticize teacher competency. ${ }^{13}$

There are three important aspects of competence that PAI teachers must have, namely: First Character, which means character that is moral (honest, trustworthy, and polite). In the soul and daily life of today's PAI teachers, it is very important to have a moral character embedded $^{14}$. Where with these moral characters the PAI teacher becomes a role model for their students. Because learning by exemplary will be more meaningful for students. Second, performance, meaning that today's Islamic education teachers must have a performance that will support every activity and activity they do, both when learning in class and other activities. Competencies that modern Islamic education teachers must have are critical, creative, collaborative, and communicative. The goal is that the ongoing learning process can lead students to become a generation that is ready to face the challenges of changing times. Third, literacy, which means that the PAI teacher's competence must be literate in various fields. At least able to master basic literacy such as financial literacy, digital, science, and culture. The goal is to present innovative and varied learning, not monotonous, which only relies on one learning method that makes students unable to develop. ${ }^{15}$

Then, what is meant by the competence of today's PAI teachers? What are the challenges of today's PAI teachers in the era of the industrial revolution 4.0? How is the competence of today's PAI teachers in facing the challenges in the era of the industrial revolution 4.0? Therefore, it is different from previous studies which discussed a lot about teacher professionalism in facing the era of the industrial revolution 4.0. In particular, this research is to examine and describe how the competence of today's teachers in facing challenges in the era of the industrial revolution 4.0.

\section{METHOD}

This research is a conceptual study, in which the author bases on data sources or references in the form of text from the opinions of experts that have been formulated in the form of books, journals, and others. Strictly speaking, it is commonly referred to as library research. As a process of understanding the text data, the writer then interprets it using the analysis description method, which starts with systematic and consistent data collection, which is then analyzed, selected and combined to then draw conclusions using deductive analysis, from general problems then conclusions are drawn special

\footnotetext{
13 Syarif Yunus, "Penyebab Rendahnya Kompetensi Guru," https://www.indonesiana.id/read/119880/empat-sebab-rendahnya-kompetensi-guru, 2019.

14 Muhamad Faisal Ashaari dkk., "An Assessment of Teaching and Learning Methodology in Islamic Studies," Procedia - Social and Behavioral Sciences, Universiti Kebangsaan Malaysia Teaching and Learning Congress 2011, Volume I, December 17 - 20 2011, Pulau Pinang MALAYSIA, 59 (17 Oktober 2012): 618-26, https://doi.org/10.1016/j.sbspro.2012.09.322.

15 Mukti Ali, "Penguatan Kompetensi Guru PAI dalam Menghadapi Revolusi Industri 4.0," https://posmetropadang.co.id/penguatan-kompetensi-guru-pai-dalam-menghadapi-revolusi-industri-4-0/, 2019.
} 


\section{DISCUSSION}

\section{Millenial PAI Teacher Competencies}

Competence is the power to do a job or activity that is based on relevant abilities and tasks that are driven by the work attitude demanded by that activity with a set standard. ${ }^{16}$ The term competence itself has many meanings, including: competence is a set of intelligent actions that are full of responsibility and must be owned by someone who is considered capable of carrying out his duties in a certain field. ${ }^{17}$ The same opinion was expressed by Wibowo, that competence is the ability to carry out or perform a job or task which is based on skills and knowledge and is supported by the work attitude demanded by the job. ${ }^{18}$ In other words, competence is the mastery of a set of knowledge, skills, values and attitudes that lead to performance and is reflected in habits of thinking and acting in accordance with the profession. $^{19}$

In general, competence can be seen from two perspectives. The first perspective describes competence from an organizational point of view, where competence is described as the knowledge, expertise and abilities of an organization that can make the organization have an advantage over its competitors. The definition of competence in this case is concentrated on the competence of an organization as a whole and whole. Meanwhile, the second perspective leads to the competencies possessed by individuals. In this context, competence is defined as the identifiable characteristics of a person who does his job effectively. ${ }^{20}$

In a simple sense, teachers are professional educators with the main task of educating, teaching, guiding, directing, training, assessing, and evaluating students in early childhood education, basic education, and secondary education in the formal education pathway. ${ }^{21}$ In other words, teachers are people who are responsible for the development of their students by trying to develop all the potential of students, both affective (feeling), cognitive (creativity), and psychomotor (intention) potential. ${ }^{22}$

Therefore, in this day and age, which is synonymous with the term "nowadays", every teacher is expected to be able to filter knowledge well. Both abstract and concrete knowledge. ${ }^{23}$ Today's teachers are teachers who have professional, pedagogic, social and personal competence with characteristics that have been formulated by considering the nation's ideology, development goals, the concept of universal education, global life and

16 Erni Yuningsih, "Pengaruh Kompetensi dan Motivasi Terhadap Kinerja Pegawai Pada PT XXX," Jurnal Visionida, 5, no. 1 (2019): 32-45.

${ }^{17}$ Fu'ad Arif Noor, Kompetensi Pendidik. MI di Era Revolusi Industri 4.0, Jurnal Elementary, vol. 7, 2019. 251278

18 Ilman Ataunur dan Eny Ariyanto, "Pengaruh kompetensi dan pelatihan terhadap kinerja karyawan pt adaro energy tbk," Jurnal Telaah Bisnis 16, no. 2 (2015): 135-50.

19 Jantje Mandey Martha Ogotan, Anita Christine Runtu, "Kompetensi Sumber Daya Manusia ( SDM ) Dalam Meningkatkan Kinerja Tenaga Kependidikan pada Bagian Akademik Universitas Sam Ratulangi Manado," Kependidikan Akademik, Bagian Sam, Universitas Manado, Ratulangi Ogotan, Martha, t.t.

${ }^{20}$ Lucia Nurbani Kartika, "Pengaruh Tingkat Kompetensi Terhadap Kinerja Pegawai Administrasi Perkantoran,” Bisnis, Fakultas Kristen, Universitas Wacana, Duta XVII, no. 1 (2014): 73-90.

${ }_{21}$ M Anwar Nurkholis, "Profesionalisme Guru Di Era Revolusi Industri 4.0," Prosding Seminar Nasional Pendidikan Program Pascasarjana Universitas PGRI Palembang, 2019, 491-98.

22 Arizqi Ihsan Pratama, "inovatif Konservatif Dalam Menghadapi Era 4.0: Tantangan Guru Menyikapi Generasi Digital-Milenial," Annual Conference on Islamic Education and Social Sains (ACIEDSS 2019) 1, no. 1 (2019): 23-33.

${ }^{23}$ Firman, "Kemampuan Guru Zaman Now." 
various other related elements. Teacher competence is not static, but develops dynamically in accordance with existing changes. Changes that commonly occur and require adjustment of teacher competencies, for example: career advancement, change of students being educated, developments in situations and community demands, and so on. ${ }^{24}$

Today's teachers must be able to design assessment instruments that explore all aspects concerning students, both knowledge, skills and character. All these aspects must be explored, honed and evaluated during the learning process in the classroom. In addition to designing assessment instruments, today's teachers must also be able to make assessment reports that describe the uniqueness and excellence of each student. This assessment report will be very useful for students and their parents as part of the feedback to continue to improve their educational outcomes. ${ }^{25}$

Based on the above understanding, the competence of PAI teachers today is a teacher who has knowledge, skills, values, and attitudes that are reflected in the habit of thinking and acting in carrying out the profession as a teacher with characteristics that have been formulated based on considerations of national ideology, development goals, concepts. universal education, and global life in accordance with the times.

\section{Challenges for PAI Teachers Today}

In an effort to realize the vision and mission of national education, namely to educate the nation's life, the Ministry of National Education has a vision of 2025 to produce smart and competitive Indonesians. Therefore, the 2013 curriculum was implemented which could produce productive, creative, innovative, and affective Indonesians through strengthening integrated attitudes, skills and knowledge, namely strengthening Character Education (PPK), literacy skills, and learning competencies in the XXI century, namely 4C (Communication , Collaboration, Critical Thinking and Problem Solving, and Creativity and Innovation), and HOTS (Higher Order Thinking Skill).

For this reason, teachers must be ready to improve themselves in increasing their professionalism to face the challenges in the 4.0 Revolution Era. In Law Number 14 of 2005 emphasizes that a teacher is a professional who educates, teaches, guides, directs, trains, assesses, and evaluates students in early childhood education, formal education, primary and secondary education. ${ }^{26}$

The industrial revolution 4.0 left behind a series of major changes to the overall world order. This era was marked by the process of global life, advances in science and technology, especially in the field of transformation and communication as well as cross-cultural occurrences. The changes brought about by globalization are also experienced by the world of education with teachers as practitioners. Challenges faced by teachers in the global era, such as

24 Parlindungan Pardede, "Menjadi Guru 'Zaman Now' dan Cara Pembelajaran Siswa Memasuki Era Industri 4 . 0 1," English Education Department (Pendidikan Bahasa Inggris) UKI, no. July (2019): 0-19.

${ }^{25}$ Indah Wati dan Insana Kamila, "Pentingnya Guru Professional dalam Mendidik Siswa Milenial Untuk Menghadapi Revolusi 4.0," Prosiding Seminar Nasional Pendidikan Program Pascasarjana Universitas PGRI Palembang 12 januari 20192 (2019): 364-70.

${ }^{26}$ Nurkholis, "Profesionalisme Guru Di Era Revolusi Industri 4.0." 
the rapid and fundamental developments in science and technology; the moral crisis that hit the nation and the state, the social crisis and the identity crisis as a nation. ${ }^{27}$

As professionals, teachers must continue to improve their quality as teachers and educators because of the rapid progress of science and technology in the era of globalization. Of course, the greater the challenge for teachers to educate students to become quality human resources in accordance with the goals of national education. Teachers should also not be technologically illiterate, meaning that they must learn and utilize technology as well as possible to simplify and facilitate the learning process. ${ }^{28}$

The main challenge for teachers today is not more than coping with the impact of technology and the very rapid globalization. The impact of technological developments does not only affect science, but technology also affects a person's socio-culture. This change also has a huge impact on the transformation of values that exist in society. Especially people with Eastern culture and customs like Indonesia. Millennially in Indonesia we can see the great influence of technological progress on cultural values adopted by society, both urban and rural communities. $^{29}$

Millennially, our world of education has received a lot of criticism regarding the education system which is very influential on the quality of human resources produced. One very sharp criticism is that the teaching and learning process that takes place in the world of formal education today is more about just pursuing a predetermined curriculum achievement target. So that in practice, students are forced to be able to accept all the information provided, without being given the slightest opportunity to reflect or reflect critically.

The decline in education is not the result of the implementation of the curriculum. However, due to the lack of professional skills of teachers in building education and learning in schools, it has an impact on student learning activities that are less interesting and unpleasant. The professional teacher emphasizes the teacher's ability to transfer knowledge, the teacher's ability to design strategies, and the teacher's ability to implement learning. The professionalism of a teacher is not just mastering science, technology and educational management. A professional teacher is basically determined by their attitudes, which means at the level of maturity that requires intellectual willingness and ability. Professionalism should be viewed as a position held by teachers in advancing education and learning in schools. ${ }^{30}$

The challenge for teachers in the era of the industrial revolution 4.0 was very tough compared to teachers in the previous era. In addition to mastering aspects of the scientific material being taught. Teachers are required to understand technology and always be creative and innovative. Teachers must become role models for students in the millennial generation, so that students understand the limitations of technology, so that they avoid misuse of using

27 Fitri Oviyanti, "Tantangan Pengembangan Pendidikan Keguruan di Era Global," Nadwa IAIN Walisongo 7 (2013).

${ }^{28}$ Novita Sari, “Menjadi Guru Profesional di Era Globalisasi,” Universitas PGRI Palembang, t.t.

${ }^{29}$ dan Rollies Husnani, Zaibi, "Prosiding seminar nasional pendidikan program pascasarjana universitas pgri palembang 03mei 2019," Prosding Seminar Nasional Pendidikan Program Pascasarjana Universitas PGRI Palembang, 2019, 348-56.

30 Alif Mudiono, "Keprofesionalan Guru dalam Menghadapi Pendidikan di Era Global," Prosiding Seminar Nasional KSDP Prodi S1 PGSD "Konstelasi Pendidikan dan Kebudayaan Indonesia di Era Globalisasi, t.t., 43-50. 
technology ${ }^{31}$. The challenges for teachers do not stop here, the millennial generation is not a generation that can be forced, for example by prohibiting students from carrying cellphones. Teachers in the millennial era must be more open to new thoughts. Teachers are required to educate students according to their time. As long as it does not conflict with the existing norms, of course the presence of technology should not be a problem. ${ }^{32}$

In facing the challenges of the development of the industrial revolution 4.0 era which is increasingly rapidly bringing changes in the human mindset, including a paradigm shift in improving the quality of education. Therefore, teachers have a broad role in following the paradigm shift in order to be able to lead their students to become qualified human beings. Indeed, the ideal teacher has a task that is not light, which is why in the Law of the Republic of Indonesia number 20 of 2003 concerning the National Education System article 39, teachers or known as educators are professional staff. As a professional, it means that the work of teachers cannot be done by just anyone because they are tasked with planning and implementing the learning process, assessing learning outcomes, conducting guidance and training, and conducting research and community service.

\section{Millennial Competencies of PAI Teachers in Facing the Challenges of the Industrial Revolution 4.0}

The millennial era is an era where digital technology can be accessed anywhere and anytime that can be enjoyed by all groups without exception. In it there is information that is accurate, fast and evolves with the changing times. In the world of education, students are expected to be able to use social media facilities effectively and appropriately. So it is not uncommon for students who have not been able to sort and utilize the internet properly because they tend to be easily influenced by their social environment without first considering the positive and negative impacts when interacting on the Internet. Conditions like this certainly require the role of teachers who are really able to guide, direct, and be able to filter out things that are not suitable for these deviations. ${ }^{33}$

In this case, teachers are required to have competence given the challenges in the very complex 4.0 industrial revolution era. The competencies of today's PAI teachers that must be possessed are as follows:

\section{Character}

Etymologically, the word character (English: character) comes from Greek, namely charassein which means "to engrave". The word "to engrave" can be translated "engrave, paint". This meaning can be related to the perception that character is a painting of the soul which manifests in behavior. Characters in the Big Indonesian Dictionary are defined as "character, psychological traits, morals or manners that distinguish a person from another, and character. Person with character means a person with personality, behavior, character,

\footnotetext{
${ }^{31}$ Roy Soetikno dkk., "Evolving Endoscopy Teaching in the Era of the Millennial Trainee," Gastrointestinal Endoscopy 89, no. 5 (1 Mei 2019): 1056-62, https://doi.org/10.1016/j.gie.2018.11.027; Jessica G. Y. Luc dkk., "Surgeon Teachers and Millennial Learners: Bridging the Generation Gap," The Journal of Thoracic and Cardiovascular Surgery, 23 Juni 2020, https://doi.org/10.1016/j.jtcvs.2020.03.177.

32 Mahyuddin Barni, “Tantangan Pendidik di Era Millenial," Jurnal Transformatif 3, no. 1 (2019): 99-116.

33 Anggun Wulan Fajriana dan Mauli Anjaninur Aliyah, "Tantangan Guru dalam Meningkatkan Mutu Pendidikan Agama Islam di Era Melenial,” Jurnal Pendidikan Islam Nað̧bruna 2, no. 2 (2019): 246-65.
} 
character, or character. This meaning shows that character is identical to personality or morals. ${ }^{34}$

Simon Philips, as quoted by Mansur Muslich, argues, character is a collection of values that lead to a system that underlies the thoughts, attitudes and behaviors that are displayed. Meanwhile, according to Imam Ghozali, he considers that character is closer to morals, namely human spontaneity in attitude, or actions that have been integrated in humans so that when it appears there is no need to think about it again, thus the character of the nation is a condition of character which is the identity of the nation. ${ }^{35}$

Teachers have a very strategic function, role and position in national development in the field of education, so that the teaching profession needs to be developed as a dignified profession $^{36}$. A teacher has a duty and a role for the environment both to students, parents, and the environment in which he teaches. The teacher has roles, namely the teacher must teach, guide and occupy, evaluate, counsel, and provide innovation. ${ }^{37}$

According to Suparlan, quoting from al-Ghazali in his book entitled "Ibya" Ulum alDin" this figure in religious education stated that effective teachers must have personal and social characteristics as follows: a) have sympathy for students, perceive and serve them as his own son. b) following the conduct and traditions of the Prophet Muhammad and he did not ask for affixes because of his service. c) do not give students arbitrary advice or justify them carrying out a task unless they are properly trained and experienced in the subject matter. d) in determining students to abandon mistreatment by giving advice rather than scolding them. e) never underestimate the discipline in front of students. f) never force something that the student cannot possibly achieve. g) provide less intelligent students with easy to understand material. According to Santrock, the character of an effective teacher is mastering subject matter and expertise or good teaching skills, has a good teaching strategy and is supported by goal-setting methods, teaching design and classroom management, and requires commitment and motivation such as good attitudes and attention to students. ${ }^{38}$

Imam Al-Mawardi said that the teacher is a person who has the virtue of the knowledge he has, who will always develop and give him benefits and kindness to the owner. Meanwhile, according to Ibn Sahnun a teacher is someone who occupies a position as a substitute for parents for their students in addition to acting as their teacher and educator. A teacher should devote his attention directly to students at school and after school and confirm

${ }^{34}$ Samrin, "Pendidikan Karakter (Sebuah Pendekatan Nilai)," Jurnal Al-Ta'dib 9, no. 1 (2016): 120-43.

35 Dian Arif Noor Pratama, "Tantangan Karakter Di Era Revolusi Industri 4.0 Dalam Membentuk Kepribadian Muslim," Al-Tanzim: Jurnal Manajemen Pendidikan Islam 3, no. 1 (2019): 198-226, https://doi.org/10.33650/al-tanzim.v3i1.518.

36 Marvin W. Berkowitz dan Melinda C. Bier, "Research-Based Character Education," The Annals of the American Academy of Political and Social Science, 8 September 2016, https://doi.org/10.1177/0002716203260082; Danilo Garcia, Trevor Archer, dan Ann-Christine Andersson Arntén, Character, Responsibility, and Well-Being: Influences on Mental Health and Constructive Behavior Patterns, 2016.

37 Hilmi Abdul Azis Anna Armeini Rangkuti, "Gambaran Karakteristik Kepribadian Dan Nilai Guru Efektif Yang Disukai Berdasarkan Perspektif Siswa Sekolah Negeri Di Jakarta Timur," JPPP - Jurnal Penelitian dan Pengukuran Psikologi 3, no. 2 (2014): 74-79, https://doi.org/10.21009/jppp.032.05.

${ }_{38}$ Dzulkifli dan Inda Puspita Sari, "Karakteristik Guru Ideal," Seminar Psikologi \& Kemanusiaan, 2015, 89_ 93. 
the arrival of each student to his home. A teacher has a role to educate students as an integral part of all aspects of life because he acts as a father. ${ }^{39}$

The urgency of teacher character for students in the industrial revolution era is not only formed through lessons, instructions, and prohibitions. Because the mental nature of accepting that virtue is not enough to say do this and don't do it. Education will not be successful without being accompanied by good and real examples. The character of the teacher through the most effective examples that must be applied and practiced by the teacher in order to form a person who has character, faith, and devotion to Allah SWT.

Noble morals are behavior based on religious teachings, social norms that do not conflict with the customs of the local community. Therefore, universally, noble morals can be accepted by anyone and anywhere. According to Edi Suardi as quoted by Ramayulis in his book "Islamic Education", states that there are two examples of teachers in shaping the character of students in the industrial revolution era, namely: 1) deliberately acting to be consciously imitated by students, 2) behaving accordingly with the norms that will be implanted so that deliberately become role models for students. ${ }^{40}$

The challenge faced by teachers is the flow of globalization where information is available without limits. The teacher must be able to bridge and direct the incoming external cultural influences. Cultivating character is one of the big challenges faced by teachers, especially when moral degradation has occurred everywhere. One of the difficulties is, sometimes there is no support and synergy with parents. Teachers who intended to correct children's attitudes were actually reported or protested by parents who did not accept that their children were disciplined. In the learning process of Islamic Religious Education the manifestation of the behavior of the teacher as teacher and student as student is seen in the interaction between the two. In this interaction, there is a process of mutual influence so that behavior changes occur in students in the form of achieving learning objectives.

Thus the character of today's PAI teachers in an effort to face the challenges of the industrial revolution 4.0 is a behavior or deed that is good and appropriate for students to do so, both in words or actions that can be applied in everyday life by students in schools and society. The criteria for the character of PAI teachers are being fair, being patient, compassionate, dignified, keeping away from disgraceful acts, having knowledge and skills, educating and guiding, and cooperating democratically.

\section{Performance}

According to August W. Smith, as quoted by Sedarmayanti, performance is "output drive processes, human or otherwise". That is, performance is the result or output of a process. Meanwhile, according to Prawirosentono, performance is the result of work that can be achieved by a person or group of people in an organization, in accordance with their respective authorities and responsibilities in order to achieve the goals of the organization concerned legally, does not violate the law and is in accordance with morals and ethics. In line with this definition, Alamsyah and Muslim define performance as "the achievements of a person, group of people, or institution in relation to the position and role they have." The

39 Pratama, "inovatif Konservatif Dalam Menghadapi Era 4.0: Tantangan Guru Menyikapi Generasi Digital-Milenial."

${ }^{40}$ Ramayulis, Ilmu Pendidikan Islam (Jakarta: Kalam Mulia, 1998). 181 
definitions of performance above indicate that performance is identical to work performance. $^{41}$

To find out whether a teacher's performance is optimal or not, it can be seen from various indicators. According to Simamora, the performance indicators include: (1) decisions on all the rules set by the organization; (2) able to carry out the job or task without error (or with the lowest error rate); and (3) accuracy in carrying out tasks. Performance measures in general which are then translated into basic behavioral assessments include: (1) quality of work; (2) quantity of work; (3) knowledge of work; (4) opinions or statements conveyed; (5) decisions taken; (6) work planning; and 7) work organization area. Meanwhile, performance for teachers in general can be measured through: (1) ability to plan; (2) ability to carry out lesson plans; (3) ability to carry out evaluations; and (4) ability to follow up on evaluation results. $^{42}$

According to Gao and Liu, there are six things that make a teacher an effective teacher, namely, teacher knowledge, professional attitude, performance in class, ability to build relationships, ability to motivate and personality. In addition, pedagogic skills and didactic training are required. Based on the opinions of the researchers above, we can assume that personality is an aspect that determines the success of teachers in the classroom. ${ }^{43}$

So with these duties and characteristics the teacher must continuously improve their teaching knowledge and techniques. A gadget must be maximized to access a lot of information so that they are not inferior to their students and download the application needed by the teacher. In essence, the teacher profile must have a qualified capacity because it is expected to be able to face the millennial generation so as to give birth to a generation that is intelligent and has character.

Based on the description above, it can be concluded that teacher performance is the result achieved by the teacher in implementing quality teaching tasks. In this study, teacher performance is intended as performance in the implementation of teaching tasks with four indicators, namely: (1) performance in lesson planning, (2) performance in learning, (3) performance in learning assessment, and (4) performance in professional development. The aspects in these four indicators are used as the minimum standard of teacher performance in this study.

\section{Literacy}

The industrial revolution 4.0 has brought many changes in human life, which has fundamentally changed the way human activities have had an impact on the world of work. The positive effect of the 4.0 industrial revolution is in the form of effectiveness and efficiency of resources even though it has an impact on reducing employment. The industrial revolution needs teachers who have competencies in digital literacy, technology, and human literacy.

${ }^{41}$ Nyayu Khodijah, "Kinerja Guru Madrasah Dan Guru Pendidikan Agama Islam Pasca Sertifikasi Di Sumatera Selatan," Jurnal Cakrawala Pendidikan 5, no. 1 (2013): 91-102, https://doi.org/10.21831/cp.v5i1.1263.

42 Pratama, "Tantangan Karakter Di Era Revolusi Industri 4.0 Dalam Membentuk Kepribadian Muslim."

43 Anna Armeini Rangkuti, "Gambaran Karakteristik Kepribadian Dan Nilai Guru Efektif Yang Disukai Berdasarkan Perspektif Siswa Sekolah Negeri Di Jakarta Timur.” 
According to Darwin's theory, "It is not the strongest who are able to survive, but the most active in responding to change". Not just senior teachers, they still don't want to change their mindset, because they will be left behind. Teachers must be willing to change their mindset and point of view, because students and the problems they face will continue to change and develop. There must be a strong motivation from the teacher to change, either intrinsic or extrinsic motivation. ${ }^{44}$

In this era of disruption, teachers must have strong competence, possess soft skills, namely critical, creative, communicative and collaborative thinking. The teacher's role as a character role model, spreads passion and inspires. This is a role that technology cannot replace. Teachers must be able to build an atmosphere that can meet the psychological needs of students, which includes: needs for competence, every student needs to feel able, meaning that interactions in learning can make students feel they can. This can be done by giving appreciation for the learning outcomes of students. Needs for Autonomy, every student needs to feel "autonomous" with freedom and trust because every autonomous learner will not depend on the teacher for learning. Needs for relatedness, each student needs to feel he is part of a group, and interact in groups. So the learning process must be able to foster collegiality interaction and mutual support. Sustainable learning, so that students are able to go through the era of disruption and enter a new era called the Abundant Era, which is an abundance of information, media and learning resources. ${ }^{45}$

The biggest challenge faced by the average teacher has to do with IT. Weaknesses in IT can be overcome by being willing to learn. Millennially, many facilities are offered both from schools and outside parties to assist teachers in improving their IT skills. ${ }^{46}$ The central government and local governments should be able to collaborate more to build good education, quality and quantity after the enactment of the regional autonomy law. The management of education, including teachers, is under the authority of the district/city government. In this regard, Winingsih, (2013) argues that the district/city government is the party most responsible for fostering and developing teacher professionalism. One form of teacher professional development is increasing teacher ICT competence by: (a) training/ training (conventional or online); (b) provision of infrastructure; (c) content; (d) motivation (reward). Furthermore, it is said that one of the most frequently used ways to increase the competence of personnel is education and training. Implementers of training or schools must understand well the concept of effective training for teachers, which is in accordance with the characteristics and needs of teachers. ${ }^{47}$

Schools also have to always hold e-module workshops, e-report cards, write online questions, use Android in learning, make interactive quizzes, make learning videos and so on. Learning creativity is also a challenge for teachers. Communicative learning, fun, prioritizing

\footnotetext{
44 Kompasiana, "Guru di Era Revolusi Industri 4.0," https://www.kompasiana.com/amp/baldwine_honest/guru-di-era-revolusi-industri-4.0, t.t.
45 Masduki Duryat, "Performance Guru:Tantangan di Era Revolusi Industri 4.0," https://www.kangduki.id/performance-guru-tantangan-di-era-revolusi-industri-4-0, 2020.

${ }^{46}$ Retnaningsih, "Tantangan dan Strategi Guru di Era Revolusi Industri 4.0 dalam Meningkatkan Kualitas Pendidikan."

47 Rahmi Rivalina, "Kompetensi Teknologi Informasi Dan Komunikasi Guru Dalam Peningkatan Kualitas Pembelajaran," Jurnal Teknodik 18, no. 2 (2014): 165-76.
} 
critical thinking, cooperation are things that need to be instilled in every learning activity. Teachers must upgrade their abilities. In this case, the main challenge lies within the teacher himself, namely willingness and professionalism. This means that professionalism is a challenge that must be overcome by teachers. Now teachers have been recognized as a profession. As a profession, there are demands for professionalism that must be met so that teachers cannot stop to continue to develop themselves. This inner challenge is a challenge that is difficult to overcome. These challenges include: it is difficult to change mindsets, it is difficult to beat laziness to learn, is not creative and innovative, lacks IT and digital technology skills/skills and does not want to upgrade knowledge.

The demands of professionalism have forced teachers to develop themselves through literacy activities, work through writing (scientific publications) and innovate by making various learning tools. This change is not optimal and comprehensive. However, these pioneering teachers will spark the enthusiasm of other teachers to improve their quality as well. A conducive climate is absolutely necessary in this case. So, what the teacher must prepare is to have "21st Century Character", namely: first, the teacher must have a passion for learning. This is necessary so that teachers master the values, social and psychological development of the ever-changing society. Second, developing effective, creative and innovative learning media so that all the knowledge conveyed by the teacher can reach students. Third, upgrade technology capabilities because teachers really need both in planning, implementing and evaluating learning. Fourth, have a high sense of empathy because the teacher's job is not only to teach but also to educate. Teachers must be able to instill values of kindness in the hearts of students, form good character and have faith based on their respective religions and beliefs. Fifth, fix yourself in order to be able to be a good role model for students. ${ }^{48}$

In learning, teachers must be clever in using an approach wisely and wisely, the teacher's view of students will determine attitudes and actions. Every teacher does not always have the same view in assessing students. This will affect the approach that teachers take in learning. The era of globalization will continue to be marked by rapid progress in science and technology, especially production and information technology. Technological advances have allowed efficiency in the use of materials and production in large quantities in a relatively short time. The emphasis on product quality is none other than having to be able to compete and meet international standards.

Meanwhile, the use of technology requires the ability and expertise of a professional workforce. Without human resources who have adequate expertise, advanced technology and sophisticated equipment that are so expensive will not bring benefits, maybe even cause disaster. Therefore, the use of advanced technology must be supported by human resources who are of high quality, professional, able to compete at the international level and continuously able to improve their quality in accordance with the demands of the increasingly growing work.

${ }^{48}$ Retnaningsih, "Tantangan dan Strategi Guru di Era Revolusi Industri 4.0 dalam Meningkatkan Kualitas Pendidikan." 


\section{CONCLUSION}

The challenge faced by Islamic education teachers in the era of the industrial revolution 4.0 is overcoming the impact of technology and very rapid globalization. Technological developments that do not only have an impact on science, but can further affect a person's socio-culture. The moral crisis that hit the nation and the state, the social crisis and the identity crisis as a nation require Islamic education teachers to continue to improve their quality as teachers and educators due to the rapid progress of science and technology in the era of globalization. The competencies that modern Islamic education teachers must have in facing the challenges of the 4.0 industrial revolution are character, performance, and literacy.

\section{REFERENCES}

Adiyoso, Wignyo, dan Hidehiko Kanegae. "The Preliminary Study of the Role of Islamic Teaching in the Disaster Risk Reduction (A Qualitative Case Study of Banda Aceh, Indonesia)." Procedia Environmental Sciences, The 3rd International Conference on Sustainable Future for Human Security, SUSTAIN 2012, 3-5 November 2012, Clock Tower Centennial Hall, Kyoto University, JAPAN, 17 (1 Januari 2013): 918-27. https://doi.org/10.1016/j.proenv.2013.02.110.

Alda, Rivika, Helen Boholano, dan Filomena Dayagbil. "Teacher Education Institutions in the Philippines towards Education 4.0." International Journal of Learning, Teaching and Educational Research 19, no. 8 (26 September 2020). http://www.ijlter.org/index.php/ijlter/article/view/2449.

Alfurqan, Alfurqan, M. Tamrin, Zulvia Trinova, dan Zuhdiyah Zuhdiyah. "The Problematics of Islamic Religious Education Teacher In Using of Instructional Media at SD Negeri 06 Pancung Soal Pesisir Selatan.” Al-Ta Lim Journal 26, no. 1 (28 Februari 2019): 5664. https://doi.org/10.15548/jt.v26i1.526.

Ali, Mukti. "Penguatan Kompetensi Guru PAI dalam Menghadapi Revolusi Industri 4.0." https://posmetropadang.co.id/penguatan-kompetensi-guru-pai-dalam-menghadapirevolusi-industri-4-0/, 2019.

Andres, Hayward P. "Active teaching to manage course difficulty and learning motivation." Journal of Further and Higher Education 43, no. 2 (7 Februari 2019): 220-35. https://doi.org/10.1080/0309877X.2017.1357073.

Anna Armeini Rangkuti, Hilmi Abdul Azis. "Gambaran Karakteristik Kepribadian Dan Nilai Guru Efektif Yang Disukai Berdasarkan Perspektif Siswa Sekolah Negeri Di Jakarta Timur." JPPP - Jurnal Penelitian dan Pengukuran Psikologi 3, no. 2 (2014): 74-79. https://doi.org/10.21009/jppp.032.05.

Arumsari, Dian. "Pengaruh Media Pembelajaran Dan Keterampilan Pengelolaan Kelas Terhadap Prestasi Belajar Siswa SMK Negeri 5 Madiun." Assets: Jurnal Akuntansi Dan Pendidikan 6, no. 1 (30 April 2017): 13-25. https://doi.org/10.25273/jap.v6i1.1290.

Ashaari, Muhamad Faisal, Zainab Ismail, Anuar Puteh, Mohd Adib Samsudin, Munawar Ismail, Razaleigh Kawangit, Hakim Zainal, Badlihisham Mohd Nasir, dan Mohd Ismath Ramzi. "An Assessment of Teaching and Learning Methodology in Islamic Studies." Procedia - Social and Behavioral Sciences, Universiti Kebangsaan Malaysia 
Teaching and Learning Congress 2011, Volume I, December 17 - 20 2011, Pulau Pinang MALAYSIA, $59 \quad$ (17 Oktober 2012): 618-26. https://doi.org/10.1016/j.sbspro.2012.09.322.

Ataunur, Ilman, dan Eny Ariyanto. "Pengaruh kompetensi dan pelatihan terhadap kinerja karyawan pt adaro energy tbk." Jurnal Telaah Bisnis 16, no. 2 (2015): 135-50.

Avalos, Beatrice. "Chapter 9 Teacher Professional Development in Teaching and Teacher Education." Dalam From Teacher Thinking to Teachers and Teaching: The Evolution of a Research Community, 19:175-204. Advances in Research on Teaching 19. Emerald Group Publishing Limited, 2013. https://doi.org/10.1108/S14793687(2013)0000019012.

Baharun, Hasan, dan Rohmatul Ummah. 'Strengthening Students' Character in Akhlaq Subject Through Problem Based Learning Model." Tadris: Jurnal Keguruan Dan Ilmu Tarbiyah 3, no. 1 (29 Juni 2018): 21-30. https://doi.org/10.24042/tadris.v3i1.2205.

Berkowitz, Marvin W., dan Melinda C. Bier. "Research-Based Character Education." The Annals of the American Academy of Political and Social Science, 8 September 2016. https://doi.org/10.1177/0002716203260082.

Brandmiller, Cornelius, Hanna Dumont, dan Michael Becker. "Teacher Perceptions of Learning Motivation and Classroom Behavior: The Role of Student Characteristics." Contemporary Educational Psychology, 11 Juni 2020, 101893. https://doi.org/10.1016/j.cedpsych.2020.101893.

Chhapra, Sadaf Umer, Saba Naz, Mehmood Usmani, dan Adil Mohiuddin. "Analysis of Students Perception about Teachers' Personality in the Academic Achievement." TARBIYA: Journal of Education in Muslim Society 5, no. 1 (28 Juni 2018): 101-15. https://doi.org/10.15408/tjems.v5i1.7098.

Collins, Ann Ryan. Teacher in faith and virtue: Lanfranc of Bec's commentary on Saint Paul. Commentaria, v. 1. Leiden; Boston: Brill, 2007.

Daryanto. Media Pembelajaran. Bandung: Satu Nusa, 2011.

Dzulkifli, dan Inda Puspita Sari. "Karakteristik Guru Ideal." Seminar Psikologi \& Kemanusiaan, 2015, 89-93.

Edward Howe, dan Masahiro Arimoto. "Narrative Teacher Education Pedagogies from across the Pacific." Dalam International Teacher Education: Promising Pedagogies (Part A), 22:213-32. Advances in Research on Teaching 22. Emerald Group Publishing Limited, 2014. http://www.emeraldinsight.com/doi/full/10.1108/S1479368720140000022014.

Fajriana, Anggun Wulan, dan Mauli Anjaninur Aliyah. "Tantangan Guru dalam Meningkatkan Mutu Pendidikan Agama Islam di Era Melenial.” Jurnal Pendidikan Islam Naz̧bruna 2, no. 2 (2019): 246-65.

Firman, Dahliana dan. “Kemampuan Guru Zaman Now.” Article, no. January (2019): 1-6.

Garcia, Danilo, Trevor Archer, dan Ann-Christine Andersson Arntén. Character, Responsibility, and Well-Being: Influences on Mental Health and Constructive Behavior Patterns, 2016.

Gewati, Michael. "Era Revolusi Industri Peran Guru Tak Tergantikan." https://edukasi.kompas.com/read/2018/11/28/17550091/di-era-revolusi-industri40-peran-guru-tak-tergantikan-tapi?page=all, diakses 02 Juni 2020, 2018. 
Husnani, Zaibi, dan Rollies. "Prosiding seminar nasional pendidikan program pascasarjana universitas pgri palembang 03mei 2019." Prosding Seminar Nasional Pendidikan Program Pascasarjana Universitas PGRI Palembang, 2019, 348-56.

Kartika, Lucia Nurbani. "Pengaruh Tingkat Kompetensi Terhadap Kinerja Pegawai Administrasi Perkantoran.” Bisnis, Fakultas Kristen, Universitas Wacana, Duta XVII, no. 1 (2014): 73-90.

Khodijah, Nyayu. "Kinerja Guru Madrasah Dan Guru Pendidikan Agama Islam Pasca Sertifikasi Di Sumatera Selatan.” Jurnal Cakrawala Pendidikan 5, no. 1 (2013): 91-102. https://doi.org/10.21831/cp.v5i1.1263.

Kompasiana. "Guru di Era Revolusi Industri 4.0." https://www.kompasiana.com/amp/baldwine_honest/guru-di-era-revolusi-industri4.0, t.t.

Luc, Jessica G. Y., Mara B. Antonoff, Ara A. Vaporciyan, dan Bobby Yanagawa. "Surgeon Teachers and Millennial Learners: Bridging the Generation Gap." The Journal of Thoracic and Cardiovascular Surgery, 23 Juni 2020. https://doi.org/10.1016/j.jtcvs.2020.03.177.

Ma'arif, Muhammad Anas. "Analisis Konsep Kompetensi Kepribadian Guru PAI Menurut Az-Zarnuji." ISTAWA 2, no. 2 (2017): 35-60. http://journal.umpo.ac.id/index.php/istawa/article/view/624.

Mahyuddin Barni. "Tantangan Pendidik di Era Millenial." Jurnal Transformatif 3, no. 1 (2019): 99-116.

Martha Ogotan, Anita Christine Runtu, Jantje Mandey. "Kompetensi Sumber Daya Manusia ( SDM ) Dalam Meningkatkan Kinerja Tenaga Kependidikan pada Bagian Akademik Universitas Sam Ratulangi Manado." Kependidikan Akademik, Bagian Sam, Universitas Manado, Ratulangi Ogotan, Martha, t.t.

Masduki Duryat. "Performance Guru:Tantangan di Era Revolusi Industri 4.0." https://www.kangduki.id/performance-guru-tantangan-di-era-revolusi-industri-4-0, 2020.

Mudiono, Alif. "Keprofesionalan Guru dalam Menghadapi Pendidikan di Era Global." Prosiding Seminar Nasional KSDP Prodi S1 PGSD "Konstelasi Pendidikan dan Kebudayaan Indonesia di Era Globalisasi, t.t., 43-50.

Muhibbin Syah. Psikologi Pendidikan dengan Pendekatan Baru. Bandung: PT. Remaja Rosdakarya, 2008.

Noor, Fu'ad Arif. Kompetensi Pendidik MI di Era Revolusi Industri 4.0. Jurnal Elementary. Vol. 7, 2019.

Nurkholis, M Anwar. "Profesionalisme Guru Di Era Revolusi Industri 4.0." Prosding Seminar Nasional Pendidikan Program Pascasarjana Universitas PGRI Palembang, 2019, 491-98.

Oviyanti, Fitri. "Tantangan Pengembangan Pendidikan Keguruan di Era Global." Nadwa LAIN Walisongo 7 (2013).

Pardede, Parlindungan. "Menjadi Guru ' Zaman Now' dan Cara Pembelajaran Siswa Memasuki Era Industri 4 . 0 1.” English Education Department (Pendidikan Bahasa Inggris) UKI, no. July (2019): 0-19. 
Pratama, Arizqi Ihsan. "inovatif Konservatif Dalam Menghadapi Era 4.0: Tantangan Guru Menyikapi Generasi Digital-Milenial." Annual Conference on Islamic Education and Social Sains (ACIEDSS 2019) 1, no. 1 (2019): 23-33.

Pratama, Dian Arif Noor. "Tantangan Karakter Di Era Revolusi Industri 4.0 Dalam Membentuk Kepribadian Muslim." Al-Tanzim: Jurnal Manajemen Pendidikan Islam 3, no. 1 (2019): 198-226. https://doi.org/10.33650/al-tanzim.v3i1.518.

Ramayulis. Ilmu Pendidikan Islam. Jakarta: Kalam Mulia, 1998.

Retnaningsih, Duwi. "Tantangan dan Strategi Guru di Era Revolusi Industri 4.0 dalam Meningkatkan Kualitas Pendidikan.” Prosiding Seminar Nasional, no. September (2019): 23-30. https://doi.org/ISBN: 9788-602-53231-4-0.

Rivalina, Rahmi. "Kompetensi Teknologi Informasi Dan Komunikasi Guru Dalam Peningkatan Kualitas Pembelajaran." Jurnal Teknodik 18, no. 2 (2014): 165-76.

Samrin. "Pendidikan Karakter (Sebuah Pendekatan Nilai)." Jurnal Al-Ta'dib 9, no. 1 (2016): 120-43.

Sari, Novita. "Menjadi Guru Profesional di Era Globalisasi." Universitas PGRI Palembang, t.t.

Soetikno, Roy, Jennifer M. Kolb, Tiffany Nguyen-Vu, Channa R. Jayasekera, Roel Bogie, Jessica Yu, Ravishankar Asokkumar, Silvia Sanduleanu, dan Tonya Kaltenbach. "Evolving Endoscopy Teaching in the Era of the Millennial Trainee." Gastrointestinal Endoscopy 89, no. 5 (1 Mei 2019): 1056-62. https://doi.org/10.1016/j.gie.2018.11.027.

Susanti, Ernita; Rifa'tu; Maulidah; yanti Sofi Makiyah. "Peran Guru Fisika Di Era Revolusi Industri 4.0." Jurnal Diffraction 1, no. 1 (2019): 48-52.

Syarif Yunus. "Penyebab Rendahnya Kompetensi Guru." https://www.indonesiana.id/read/119880/empat-sebab-rendahnya-kompetensi-guru, 2019.

Uak, Uda. "Karakteristik Guru Zaman Now." https://www.matrapendidikan.com/2018/01/karakteristik-guru-zaman-now.html, 2018.

Wati, Indah, dan Insana Kamila. "Pentingnya Guru Professional dalam Mendidik Siswa Milenial Untuk Menghadapi Revolusi 4.0." Prosiding Seminar Nasional Pendidikan Program Pascasarjana Universitas PGRI Palembang 12 januari 20192 (2019): 364-70.

Yuningsih, Erni. "Pengaruh Kompetensi dan Motivasi Terhadap Kinerja Pegawai Pada PT XXX.” Jurnal Visionida, 5, no. 1 (2019): 32-45. 